\title{
SIMULASI PERBAIKAN TEGANGAN DENGAN PEMASANGAN TURBIN ANGIN PADA SISTEM DISTRIBUSI RADIAL KOTA LHOKSEUMAWE MENGGUNAKAN ETAP
}

\author{
M. Syakirman, Andik Bintoro, Arnawan Hasibuan
}

\author{
Jurusan Teknik Elektro, Fakultas Teknik Universitas Malikussaleh \\ Kampus Bukit indah, Jalan Batam No. 06 Kecamatan Blangpulo Lhokseumawe \\ E-mail : andik@unimal.ac.id
}

\begin{abstract}
Abstrak - Pengaruh dari pemasangan turbin angin terhadap perbaikan jatuh tegangan pada gardu hubung Hagu-06 Kota Lhokseumawe. Untuk penempatan turbin angin, ditempatkan pada bus yang terjadi jatuh tegangan paling banyak. Dari hasil yang telah diperoleh dengan pemasangan turbin angin dapat memperbaiki jatuh tegangan yang terjadi. Dimana saat kondisi malam saat terjadi jatuh tegangan, hasil tegangan yang diperoleh adalah sebesar 91,65\% atau 366,6 Volt dari 400 Volt, untuk perbaikan tegangan setelah dihubungkan turbin angin sebesar 95,91\% atau 383,64 Volt dari 400 Volt. Sedangkan turbin angin yang digunakan dalam simulasi berkapasitas daya sebesar 800 KW. Dengan pemasangan turbin angin dapat memperbaiki rugi daya aktif dan daya reaktif pada gardu hubung Hagu06.
\end{abstract}

Keywords - Turbin angin, jatuh tegangan, rugi daya

\section{PENDAHULUAN}

Mencuatnya isu krisis energi turut mempengaruhi eksistensi energi listrik. Sebagaimana diketahui bahwa sebagaian besar pusat pembangkitan untuk memproduksi energi listrik di Indonesia bersumber dari energi fosil seperti batu bara dan bahan bakar minyak. Sumber energi fosil sendiri sewaktu-waktu bisa habis jika dilakukan pemakaian terus menerus. Untuk menanggulangi masalah tersebut, saat ini mulai dikembangkan energi alternatif terbarukan secara besar-besaran untuk menghasilkan energi lisrtrik. Energi alternatif terbarukan merupakan energi yang dapat diperbaharui, ramah lingkungan dan tidak berkontribusi dalam pemanasan iklim.[1]

Secara geografis, Indonesia berpotensi besar untuk mengembangkan pembangkitan listrik energi alternatif terbarukan tersebut. Salah satunya adalah energi angin yang berhembus relatif setabil sepanjang tahun dengan rata-rata kecepatan $5 \mathrm{~m} /$ detik. Dengan menggunakan media kincir angin, energi angin yang berhembus dapat diubah menjadi energi listrik yang sangat bermanfaat. [1]

Faktor yang mendorong penulis untuk melakukan penelitian ini adalah, telah diketahui bahwa saat ini energi untuk menggerakan turbin listrik yang dibutuhkan di indonesia sudah sangat kritis seperti energi dari fosil batu bara dan bahan bakar minyak. Namun permasalahan tersebut bisa diatasi dengan memanfaatkan energi angin, yang dimana secara geografis indonesia termasuk dalam kawasan yang berpotensi untuk memanfaatkan energi angin yang berhembus secara stabil sepanjang tahun dengan kecepatan $5 \mathrm{~m} /$ detik.

\section{DASAR TEORI}

\subsection{Pengertian Pembangkit Listrik Tenaga Angin}

Pembangkit listrik tenaga angin adalah suatu pembangkit listrik yang menggunakan angin sebagai sumber energi untuk menghasilkan energi listrik. Pembangkit ini dapat merubah energi angin menjadi energi listrik dengan menggunakan turbin angin atau kincir angin. Sistem pembangkitan listrik menggunakan angin sebagai sumber energi merupakan sistem alternatif yang sangat berkembang pesat, mengingat angin merupakan salah satu energi yang tidak terbatas di alam. [4]

Pembangkit listrik tenaga angin, yang diberi nama Wind Power System memanfaatkan angin melalui kincir, untuk menghasilkan energi listrik. Alat ini sangat cocok sekali digunakan masyarakat yang tinggal di pulau-pulau kecil. Secara umum, sistem alat ini memanfaatkan tiupan angin untuk memutar motor. Hembusan angin ditangkap balingbaling, dan dari putaran baling-baling tersebut akan dihasilkan putaran motor yang selanjutnya diubah menjadi energi listrik.

\subsection{Jatuh Tegangan (Drop Voltage)}

Jatuh tegangan merupakan besarnya tegangan yang hilang pada suatu penghantar. Jatuh tegangan pada saluran tenaga listrik secara umum berbanding lurus dengan panjang saluran dan beban serta berbanding terbalik dengan luas penampang pengahantar.[6]

Jatuh tegangan juga didefinisikan sebagai selisih antara tegangan ujung pengiriman dan tegangan ujung penerimaan pada suatu jaringan. Jatuh tegangan disebabkan oleh hambatan dan arus pada saluran bolak-balik besarnya tergantung dari impedansi saluran serta pada beban dan faktor daya. Berdasarkan pengertian diatas, jatuh tegangan pada suatu saluran dapat dinyatakan dengan persamaan berikut[7]:

$$
\begin{aligned}
& \Delta \mathrm{V}=V_{s}-V_{t} \\
& \text { Dimana: } \\
& \mathrm{V} \quad=\text { Drop tegangan }(\mathrm{V}) \\
& \mathrm{Vs} \quad=\text { Tegangan kirim }(\mathrm{V}) \\
& \mathrm{Vt} \quad=\text { Tegangan terima }(\mathrm{V})
\end{aligned}
$$


Dari persamaan diatas, maka dapat di ketahui nilai jatuh tegangan relatif atau biasa dikenal dengan Voltage Regulation (VR) dengan persamaan:

$$
\mathrm{VR}=\frac{V_{s-V_{t}}}{V_{s}} \times 100 \%
$$

Untuk persamaan mencari besarnya kenaikan tegangan yang terjadi dapat menggunakan rumus dibawah ini

$$
V_{b}=V_{n}-V_{r}
$$

\section{Dimana:}

$\mathrm{Vr} \quad=$ Tegangan sebelum ada turbin angin $(\mathrm{V})$

$\mathrm{Vn}=$ Tegangan setelah ada turbin angin (V)

$\mathrm{Vb}=$ Tegangan yang naik $(\mathrm{V})$

\section{METODOLOGI}

Analisis profil tegangan saat kondisi siang dan kondisi malam dengan menggunakan software Electic Transient and Analysis Program (ETAP)12.6.0, baik sebelum penambahan turbin angin dan setelah dilakukan penambahan Turbin Angin pada sistem distribusi radial pada Gardu Hubung Kota Lhokseumawe GH Hagu 06.

\subsection{Metode pengumpulan data}

Metode pengumpulan data adalah teknik atau cara-cara yang dapat digunakan peneliti untuk mengumpulkan data. Dalam penelitian ini, metode pengumpulan data yang digunakan adalah wawancara, dan data arsip (dokumentasi). Metode-metode tersebut dapat dijelaskan lebih rinci sebagai berikut:

1. Wawancara dilakukan dengan mewawancarai narasumber yang kompeten dalam bidang yang terkait terhadap topik dari tugas akhir yang diangkat. Teknik wawancara yang dilakukan adalah menanyakan sesuatu yang tidak diketahui atau yang tidak jelas.

2. Metode dokumentasi adalah teknik pengumpulan data yang dilakukan dengan menyalin data (softcopy database) yang terkait dengan penelitian dari suatu sumber. Pada penelitian ini, salinan data diambil dari PLN Gardu Hubung Lhokseumawe dan Gardu Induk Bayu.

\subsection{Diagram satu garis}

Untuk single line diagram (SLD) penulis menggunakan sistem distribusi listrik Kota Lhokseumawe. Untuk penempatan wind turbine itu sendiri, hanya dihubungkan pada titik jaringan distribusi Hagu 06.
3.3 Diagram alir

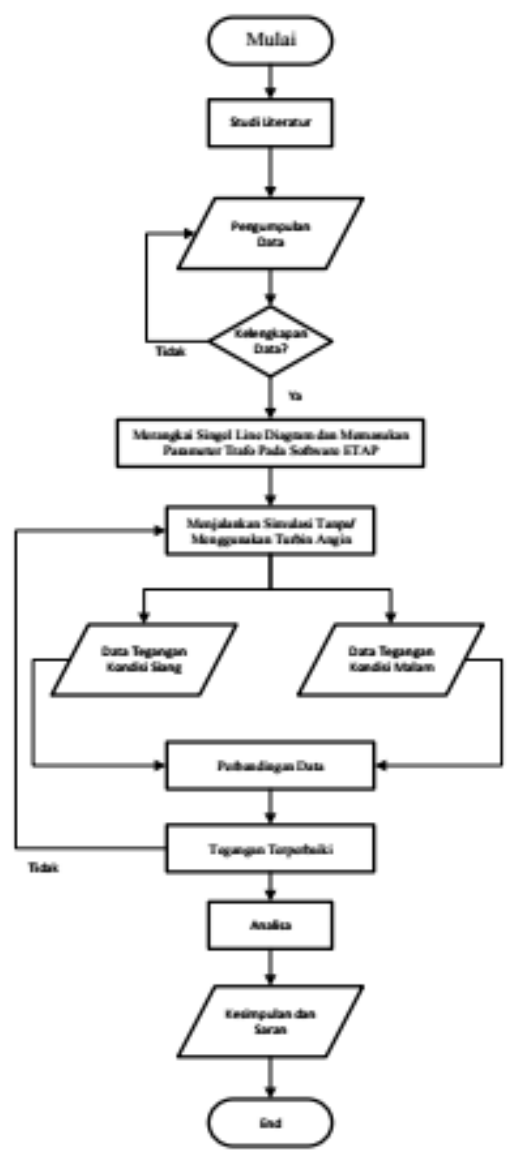

Gambar 3.1 Diagram alir penelitian

\section{ANALISA DAN PEMBAHASAN}

Untuk permodelan analisis jatuh tegangan akan dilihat perbedaan pemakaian beban listrik saat siang dan malam beserta keadaan beban yang telah diperbaiki oleh turbin angin, lalu akan diatur lumped load. Lumped load adalah salah satu beban pemakaian listrik yang ada di software ETAP. Lumped load dari setiap titik beban untuk trafo diatur sebesar $65 \%$ dari beban maksimum untuk keadaan malam, dan $25 \%$ pemakaian beban untuk kondisi siang.

4.1 Perbandingan karakteristik Tegangan Listrik Antara Siang dan Malam Beserta Perbaikan Tegangannya Pada Gardu Hubung Hagu 06

Pada simulasi percobaan perbandingan tegangan yang terjadi saat siang dan malam, penulis memasukan data beban maksimum untuk lumped load di ETAP sebesar $65 \%$ dari kapasitas trafo dari setiap lokasi. Untuk pengaturan beban saat siang penulis memasukan $25 \%$ penggunaan beban untuk setiap lumped load, dan untuk pengaturan beban saat malam 
penulis memasukan $100 \%$ penggunaan beban untuk setiap lumped load. Untuk contohnya bisa dilihat pada gambar 4.1 dibawah ini.

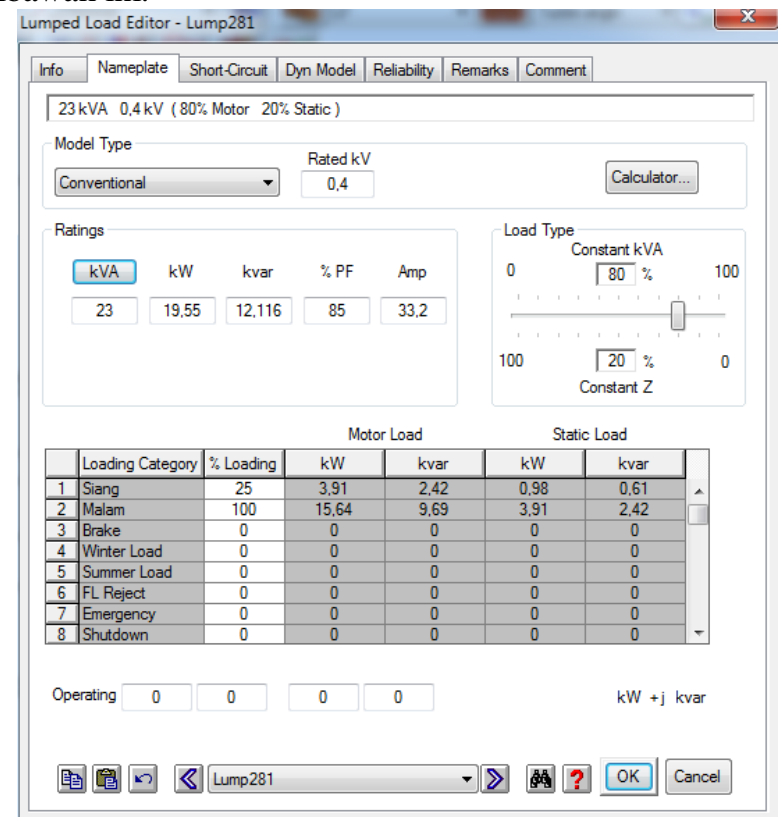

Gambar 4.1 Salah satu contoh pengaturan lumped load untuk beban siang dan malam pada software ETAP

Untuk perbaikan tegangannya penulis menghubungkan turbin angin disetiap gardu hubung Hagu 06. Dalam simulasi penulis memasukan data turbin angin untuk kapasitas dayanya sebesar $800 \mathrm{~kW}$. Untuk tegangannya penulis memasukan tegangan sebesar $20 \mathrm{KV}$, untuk selengkapnya dapat dilihat pada tabel 4.1 dan gambar 4.2 untuk konfigurasi turbin angin pada simulasi ETAP.

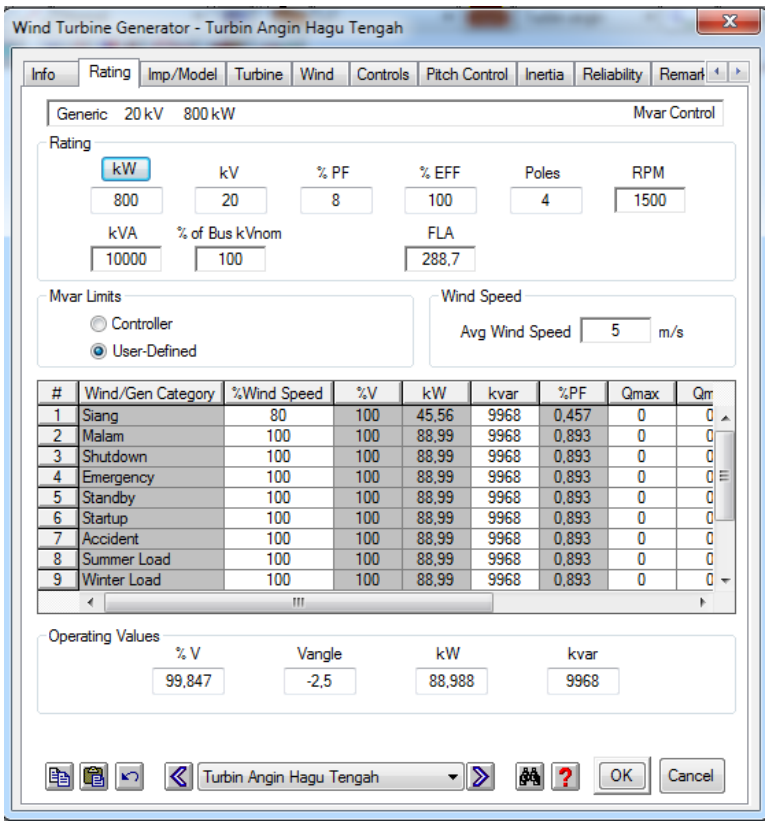

Gambar 4.2 Spesifikasi turbin angin dalam simulasi perbaikan tegangan pada siang dan malam
4.1.1 Keadaan Profil Tegangan Pada Gardu Hubung Hagu 06 Saat Siang Dan Malam Beserta Perbaikan Tegangan Dengan Menggunakan Turbin Angin

\section{Sebelum Perbaikan Dengan Turbin Angin}

Dari hasil prolehan data pada hasil simulasi software ETAP, dengan tegangan saat kondisi siang dan kondisi malam. Dari hasil tersebut dapat dilihat saat kondisi siang hasil tegangan yang terjadi saat di jalankan simulasi berkisar $98,04 \%$ sampai dengan $98,76 \%$, dengan nilai tegangannya sebesar 392,16 Volt sampai dengan 395,04 Volt dari tegangan kirim 400 volt, jadi penurunan tegangan yang terjadi dapat dicari dengan mengguna rumus (2.1).

Untuk pencarian jatuh tegangan pada trafo bus Fakultas Teknik Unimal untuk 98,04\% adalah:

Diketahui:

Tegangan kirim $(\mathrm{Vs}) \quad=400$ Volt

Tegangan terima $(\mathrm{Vt}) \quad=95,91 \%$

$94,91 \%$ x 400 volt $=383,41$ Volt

Jadi:

$$
\begin{aligned}
& \Delta \mathrm{V}=V_{s}-V_{t} \\
& \Delta \mathrm{V}=400 \mathrm{~V}-392,16 \mathrm{~V} \\
& \Delta \mathrm{V}=7,84 \mathrm{~V}
\end{aligned}
$$

Untuk pencarian jatuh tegangan pada trafo bus Sp.Besi tua Hg.Teungoh untuk 98,76\% adalah:

$$
\begin{aligned}
& \text { Diketahui: } \\
& \text { Tegangan kirim (Vs) } \quad=400 \text { Volt } \\
& \text { Tegangan terima }(\mathrm{Vt}) \quad=98,76 \% \\
& =400 \mathrm{~V} \times 98,76 \%=395,04 \text { Volt } \\
& \text { Jadi: } \\
& \Delta \mathrm{V}=V_{s}-V_{t} \\
& \Delta \mathrm{V}=400 \mathrm{~V}-395,04 \mathrm{~V} \\
& \Delta \mathrm{V}=4,96 \mathrm{~V}
\end{aligned}
$$

Jadi jatuh tegangan yang terjadi untuk $98,04 \%$ atau 392,16 Volt adalah 7,84 Volt untuk lokasi bus trafo Fakultas Teknik Unimal dan penurunan tegangan yang terjadi untuk $98,76 \%$ atau 395,04 Volt untuk lokasi bus trafo Sp.Besi tua Hg.Teungoh.

Dari data hasil simulasi dapat dilihat saat kondisi malam hasil tegangan yang terjadi saat di jalankan simulasi berkisar $91,65 \%$ sampai dengan $94,7 \%$, dengan nilai tegangannya sebesar 366,6 Volt sampai dengan 378,8 Volt dari tegangan kirim sebesar 400 volt, jadi penurunan tegangan yang terjadi dapat dicari dengan mengguna rumus (2.1).

Untuk pencarian jatuh tegangan pada trafo bus Fakultas Teknik Unimal dengan tegangan 91,65\% adalah:

Diketahui:

$$
\begin{array}{ll}
\text { Tegangan } \operatorname{kirim}(\mathrm{Vs}) & =400 \text { Volt } \\
\text { Tegangan terima }(\mathrm{Vt}) & =91,65 \%=400 \times \\
\text { 91,65\% }=366,6 \text { Volt } & \\
\text { Jadi: } & \\
\Delta \mathrm{V}=V_{s}-V_{t} \\
\begin{array}{ll}
\Delta \mathrm{V}=400 \mathrm{~V}-366,6 \mathrm{~V} \\
\Delta \mathrm{V}=33,4 \mathrm{~V}
\end{array}
\end{array}
$$


Untuk pencarian jatuh tegangan pada trafo bus Sp.Besi tua Hg.Teungoh dengan tegangan $94,7 \%$ adalah:

Diketahui:

$\begin{array}{ll}\text { Tegangan } \operatorname{kirim}(\mathrm{Vs}) & =400 \text { Volt } \\ \text { Tegangan terima }(\mathrm{Vt}) & =94,7 \%=400 \mathrm{~V} \times\end{array}$

$94,7 \%=378,8$ Volt

Jadi:

$$
\begin{aligned}
& \Delta \mathrm{V}=V_{s}-V_{t} \\
& \Delta \mathrm{V}=400 \mathrm{~V}-378,8 \mathrm{~V} \\
& \Delta \mathrm{V}=21,2 \mathrm{~V}
\end{aligned}
$$

Jadi jatuh tegangan yang terjadi untuk 91,65\% atau 366,6 Volt adalah 33,4 Volt untuk lokasi bus trafo Fakultas Teknik Unimal dan Lab.F unimal. Penurunan tegangan yang terjadi untuk $94,7 \%$ atau 378,8 Volt adalah 21,2 Volt untuk lokasi bus trafo Sp.Besi tua Hg.Teungoh.

Dalam simulasi dikatakan jika jatuh tegangan yang terjadi berada dibawah $95 \%$ dari maksimum tegangannya, maka kondisi tersebut dikatakan critical atau tegangan tersebut dalam keadaan kritis. Penyebab dari jatuh tegangan tersebut dapat dipicu dengan banyaknya kapasitas pemakaian beban yang dimana pada simulasi penulis memasukan beban untuk lumped load sebesar 65\% dari beban maksimum trafo distribusi untuk setiap titik dan juga dapat diakibatkan oleh panjangnya saluran beserta banyaknya titik trafo dan besarnya beban pada Hagu 06.

Dalam perbandingan keadaan tegangan saat kondisi siang dan malam terlihat perbandingan tegangannya pada gambar 4.7 yang disajikan dalam bentuk grafik. Terlihat keadaan tegangan saat kondisi siang dan malam terjadi perbedaan jatuh tegangan yang berbeda-beda, yang dimana jatuh tegangan paling besar terjadi pada saat kondisi malam hari. Jatuh tegangan tersebut bisa disebabkan oleh besarnya beban yang di pakai saat kondisi malam, yang dimana pada simulasi penulis memasukan beban sebesar $65 \%$ dari kapasitas trafo yang sudah disediakan.

\section{Sesudah Perbaikan Dengan Turbin Angin}

Untuk perbaikan tegangan penulis hanya menganalisis perbaikan tegangan saat kondisi malam, yang dimana saat kondisi malam rata-rata tegangannya $93,28 \%$, yang dimana dalam simulasi dikatakan jika jatuh tegangan yang terjadi berada dibawah $95 \%$ dari maksimum tegangannya, maka kondisi tersebut dikatakan critical atau tegangan tersebut dalam keadaan kritis

Dari perolehas data simulasi perbaikan dapat dilihat saat kondisi perbaikan pada malam setelah dihubungkan turbin angin tegangan yang awalnya $91,65 \%$ pada trafo bus Fakultas Teknik Unimal mengalami kenaikan menjadi $95,91 \%$, dan tegangan untuk 94,7\% pada trafo bus Sp.Besi tua $\mathrm{Hg}$.Teungoh mengalami kenaikan menjadi 96,76\%. Untuk mencari kenaikan tegangan yang terjadi dapat dicari dengan mengguna rumus.

Untuk kenaikan tegangan 95,91\% pada trafo bus Fakultas Teknik Unimal, adalah:

Diketahui:

$$
\mathrm{V}_{\mathrm{n}} \quad=95,91 \%=400 \times 95,91 \%=383,64 \text { Volt }
$$

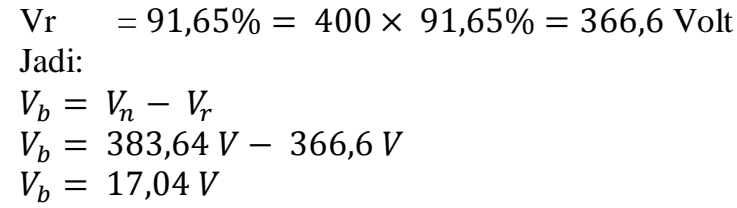

Untuk kenaikan tegangan $96,76 \%$ pada trafo bus Sp.Besi tua Hg.Teungoh, adalah:

Diketahui:

$$
\begin{aligned}
& \mathrm{V}_{\mathrm{n}} \quad=96,76 \%=400 \times 96,76 \%=387,04 \text { Volt } \\
& \mathrm{V}_{\mathrm{r}} \quad=94,7 \%=400 \mathrm{~V} \times 94,7 \%=378,8 \text { Volt } \\
& \text { Jadi: } \\
& V_{b}=V_{n}-V_{r} \\
& V_{b}=387,04 \mathrm{~V}-378,8 \mathrm{~V} \\
& V_{b}=8,24 \mathrm{~V}
\end{aligned}
$$

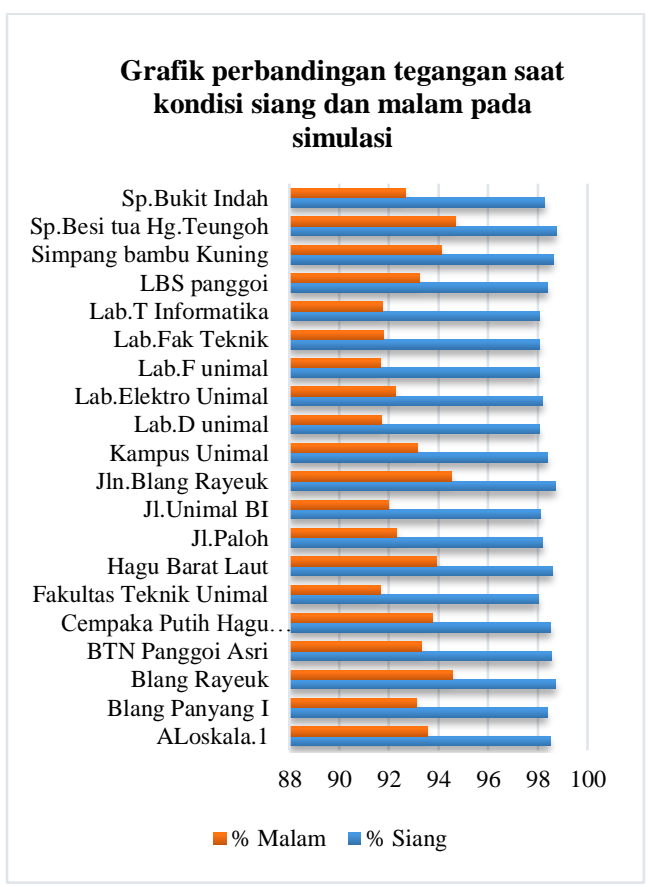

Gambar 4.3 Grafik perbandingan tegangan saat kondisi siang dan malam pada simulasi

.Dari hasil pencarian kenaikan tegangan yang terjadi pada simulasi sebelum pemasangan turbin angin, dan setelah pemasangan turbin angin, diperoleh hasil kenaikan tegangan sebesar 17,04 Volt untuk trafo bus Fakultas Teknik Unimal, yang dimana tegangan sebelum pemasangan turbin angin sebesar 366,6 Volt menjadi 383,64 Volt setelah dihubungkan turbin angin. Sedangkan untuk lokasi trafo bus Sp.Besi tua Hg.Teungoh mengalami kenaikan tegangan sebesar 8,24 Volt, yang dimana tegangan sebelum pemasangan turbin angin sebesar 378,8 Volt menjadi 387,04 Volt setelah dihubungkan turbin angin. Sedangkan untuk penurunan tegangan yang terjadi setelah dihubungkan turbin angin dapat dicari dengan mengguna rumus (2.1).

Untuk penurunan tegangan $95,91 \%$ pada trafo bus Fakultas Teknik Unimal, adalah:

Diketahui:

Tegangan kirim $\left(\mathrm{V}_{\mathrm{s}}\right) \quad=400$ Volt 


$$
\text { Tegangan terima }\left(\mathrm{V}_{\mathrm{t}}\right) \quad=\quad 95,91 \%=400 \times
$$$$
\text { Jadi: }
$$$$
\Delta \mathrm{V}=V_{s}-V_{t}
$$$$
\Delta \mathrm{V}=400 \mathrm{~V}-383,64 \mathrm{~V}
$$$$
\Delta V=16,3 V
$$

Untuk penurunan tegangan $96,76 \%$ pada trafo bus Sp.Besi tua Hg.Teungoh, adalah:

$$
\begin{aligned}
& \text { Diketahui: } \\
& \text { Tegangan kirim }\left(\mathrm{V}_{\mathrm{s}}\right) \\
& \text { Tegangan terima }\left(\mathrm{V}_{\mathrm{t}}\right) \\
& \text { Jadi: } \\
& \Delta \mathrm{V}=V_{s}-V_{t} \\
& \Delta \mathrm{V}=400 \mathrm{~V}-387,04 \mathrm{~V} \\
& \Delta \mathrm{V}=12,96 \mathrm{~V}
\end{aligned}
$$$$
\text { Tegangan kirim }\left(\mathrm{V}_{\mathrm{s}}\right) \quad=400 \text { Volt }
$$$$
\text { Tegangan terima }\left(\mathrm{V}_{\mathrm{t}}\right) \quad=96,76 \%=400 \times
$$$$
96,76 \%=387,04 \text { Volt }
$$

Jadi jatuh tegangan yang terjadi untuk $95,91 \%$ atau 383,64 Volt adalah 16,3 Volt untuk lokasi bus trafo Fakultas Teknik Unimal. Penurunan tegangan yang terjadi untuk $96,76 \%$ atau 387,04 Volt adalah 12,96 Volt untuk lokasi bus trafo Sp.Besi tua Hg.Teungoh.

Perbandingan untuk keadaan tegangan antara siang dan malam setelah perbaikan bisa dilihat pada gambar yang disajikan dalam bentuk grafik dibawah ini:

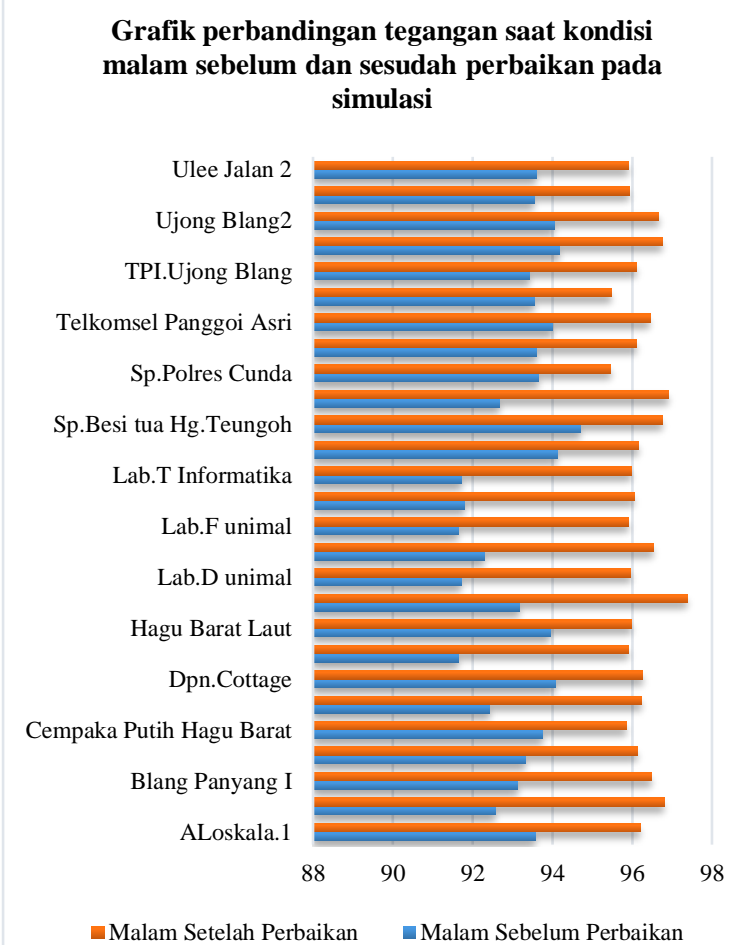

Gambar 4.4 Grafik perbandingan tegangan saat kondisi malam sebelum perbaikan dan sesudah perbaikan pada simulasi

Dalam analisis perbaikan jatuh tegangan pada gardu hubung Hagu 06 saat kondisi malam, bisa dilihat bahwa jatuh tegangan yang terjadi dapat diperbaiki dengan menaikan tegangan menggunakan turbin angin yang berkapasitas 800 KW. Sedangkan dalam pembuatan simulasi sebelum memakai turbin angin dengan daya $800 \mathrm{KW}$, daya untuk turbin angin sebesar $200 \mathrm{KW}$, dan $600 \mathrm{KW}$, dari kedua daya tersebut tidak dapat memperbaiki jatuh tegangan yang terjadi pada gardu hubung Hagu 06. Sedangkan turbin angin dengan daya $800 \mathrm{KW}$, dapat memperbaiki jatuh tegangan yang terjadi, yang awalnya dalam kondisi critical menjadi kondisi marginal.

\section{KESIMPULAN}

Kesimpulan dari penelitain ini adalah:

- Keadaan tegangan saat kondisi siang dan malam terdapat perbedaan tegangan yang berbeda, yang dimana saat kondisi siang jangkauan tegangannya berkisar dari $98,04 \%$ atau $392,16 \mathrm{~V}$ sampai dengan $98,76 \%$ atau $395,04 \mathrm{~V}$, untuk kondisi malam jangkauan tegangannya berkisar dari $91,65 \%$ atau $366,6 \mathrm{~V}$ sampai dengan $94,7 \%$ atau $378,8 \mathrm{~V}$.

- Jatuh tegangan terjadi saat kondisi malam dengan jatuh tegangan paling tinggi sebesar $33,4 \mathrm{~V}$ dari tegangan normal, dengan nilai tegangannya sebesar $366,6 \mathrm{~V}$ dari $400 \mathrm{~V}$.

- Dengan pemasangan turbin angin pada kondisi malam dapat memperbaiki tegangan, yang awalnya $91,65 \%$ atau 366,6 Volt menjadi $95,91 \%$ atau 383,64 Volt.

- Untuk perbaikan jatuh tegangan Hagu 06 dapat menggunakan turbin angin dengan kapasitas daya minimal sebesar $800 \mathrm{KW}$.

- $\quad$ Faktor yang menyebabkan jatuh tegangan pada Hagu 06 disebabkan oleh banyaknya titik beban, kapasitas pemakaian beban untuk setiap trafo hampir mendekati $65 \%$ dari daya trafo tersebut.

- $\quad$ Dengan pemasangan turbin angin dapat memperbaiki rugi daya aktif dan daya reaktif pada gardu hubung Hagu 06

\section{REFERENSI}

[1] A. B. Rahmawan, "Pengembangan Media Pembelajaran Kincir Angin Pada Mata Pelajaran Prakarya Dan Kewirausahaan," Fak. Tek. Univ. NEGERI YOGYAKARTA, p. 223, 2015.

[2] D. Y. Sukma, "Perbaikan Jatuh Tegangan pada Feeder Jaringan Distribusi Tegangan Menengah 20 kV Teluk Kuantan,” vol. 4, no. 1, pp. 1-8, 2017.

[3] A. Kurniawan, "Analisa jatuh tegangan dan penanganan pada jaringan distribusi $20 \mathrm{kv}$ rayon palur pt. pln (persero) menggunakan etap 12.6," 2016 .

[4] S. Muslim, TEKNIK PEMBANGKIT TENAGA LISTRIK JILID 1 Jakarta, 2016.

[5] F. R. DEWANTO, "PERANCANGAN TURBIN ANGIN SUMBU HORIZONTAL," Tek. MESIN Fak. Tek. Univ. JEMBER, p. 27, 2017.

[6] N. Agung, "Analisa Perbaikan Losses Dan Jatuh Tegangan Pada Jaringan Sambungan Rumah Tidak Standar Dengan," Jur. Tek. Elektro, Univ. Diponegoro Semarang, vol. 4, p. 6, 2013.

[7] H. Suyono and N. Hasanah, "Perbaikan Profil Tegangan pada Feeder Harapan Baru Lima ( H5 ) Area Samarinda untuk Pengurangan Susu Energi," vol. 7, no. 2, pp. 131-136, 2013.

[8] I. Darmana, "Perbaikan Jatuh Tegangan Dengan Pemasangan Automatic Voltage Regulator," pp. 1-22, 2013. 